\title{
PENGARUH LAMA WAKTU PENGHITUNGAN STRAW DAN POSISI JARAK STRAW DIATAS PERMUKAAN NITROGEN CAIR TERHADAP MOTILITAS DAN VIABILITAS SEMEN BEKU SAPI MADURA POST THAWING
}

\section{EFFECT OF THE DURATION OF STRAW COUNT AND THE POSITION OF STRAW FROM LIQUID NITROGEN SURFACE TO THE MOTILITY AND VIABILITY OF POST THAWING FROZZEN MADURA CATTLE}

\author{
Lutfi Ardiana ${ }^{1)}$, Hardijanto ${ }^{2)}$, Ratna Damayanti ${ }^{3)}$, Trilas Sardjito ${ }^{4)}$, \\ Imam Mustofa ${ }^{5)}$, Budi Utomo ${ }^{6}$ ) \\ ${ }^{1)}$ Mahasiswa, ${ }^{2,4,5,6}$ Departmen Reproduksi Veteriner, ${ }^{3)}$ Departmen Kedokteran Dasar Veteriner \\ Fakultas Kedokteran Hewan, Universitas Airlangga \\ luthfiardiana13@gmail.com
}

\begin{abstract}
Aims of this research was to determine the effect of the duration of straw count and the position of straw from liquid nitrogen surface to the motility and viability of post thawing frozen Madura cattle. This study used a sample derived from Madura cattle (Pasean OO 1220) from BBIB singosari as much as 54 straw divided into 9 treatments. P1 $(1 \mathrm{~cm} 10 \mathrm{sec}), \mathrm{P} 2(1 \mathrm{~cm}$ $20 \mathrm{sec})$, P3 (1 $\mathrm{cm} 40 \mathrm{sec})$, P4 ( $2 \mathrm{~cm} 10 \mathrm{sec})$, P5 ( $2 \mathrm{~cm} 20 \mathrm{sec})$, P6 (2cm $40 \mathrm{sec})$, P7 $(3 \mathrm{~cm} 10 \mathrm{sec})$, P8 $(3 \mathrm{~cm} 20 \mathrm{sec}), \mathrm{P} 9(3 \mathrm{~cm} 40 \mathrm{sec})$ and repeated as much as 6 times then observed for motility and viability of post thawing spermatozoa. The data obtained were analyzed using SPSS 16.0. The results showed that the duration of straw count and the position of straw from liquid nitrogen significant $(\mathrm{P}<0,05)$ on post thawing motility. The position of straw from liquid nitrogen signifant $(\mathrm{P}<0,05)$ on post thawing viability. The conclusion of this research showed that $1 \mathrm{~cm} 40 \mathrm{sec}$ give the higher post thawing motility.
\end{abstract}

Key words : straw of Madura cattle, distance, duration, motility, viability

\section{Pendahuluan}

Ketidakberhasilan IB di lapangan sering ditandai adanya kawin berulang (Affandhy dkk., 2006 dan Riady, 2006). Prihatno dkk. (2013) melaporkan bahwa kejadian kawin berulang di daerah Istimewa Yogyakarta (DIY) sebesar 29,4\% sedangkan Nurjayanti (2014) melaporkan di daerah Gresik sebesar 20,3\%. Faktor-faktor yang mempengaruhi keberhasilan IB antara lain kualitas semen beku, pengetahuan dan kepedulian peternak dalam melakukan deteksi birahi, body condition score (BCS) sapi, kesehatan ternak terutama yang terkait dengan alat-alat reproduksi, keterampilan dan sikap inseminator serta waktu IB yang tepat (Diwyanto, 2012 dan Caraviello et al., 2006).

Kualitas semen beku yang di produksi harus memiliki nilai Post Thawing Motility (PTM) lebih dari $40 \%$ dan gerakan individu 2-3 (SNI 4869.1: 2008). Nilai PTM tersebut dapat dipengaruhi oleh beberapa faktor yaitu teknik thawing, ketersediaan nitrogen ca- ir, handling semen beku, dan teknik pemindahan straw (Selk, 2002 dan Afiati, dkk., 2004).

Teknik pemindahan straw salah satunya pada proses penghitungan semen beku sebelum dilakukan pendistribusian, yang bertujuan menghindari kesalahan jumlah dan cacat straw. Penghitungan semen beku dilakukan pada rak di atas permukaan nitrogen cair. Proses tersebut kemungkinan dapat menurunkan nilai PTM semen beku karena akan terjadi kenaikan suhu lingkungan yang awalnya $-196^{\circ} \mathrm{C}$ tercelup didalam nitrogen cair.

Berdasarkan latar belakang di atas perlu dilakukan penelitian di Balai Besar Inseminasi Buatan Singosari untuk mengetahui pengaruh lama waktu penghitungan straw dan posisi jarak straw di atas permukaan nitrogen cair pada proses penghitungan semen beku terhadap motilitas dan viabilitas semen beku sapi Madura, sehingga diharapkan tidak akan terjadi penu- 
runan kualitas semen beku sapi Madura sampai dapat digunakan oleh peternak.

\section{Metode Penelitian \\ Sampel Penelitian}

Sampel yang digunakan dalam penelitian ini adalah produk semen beku sapi Madura (straw) dengan nama pejantan $\mathrm{Pa}$ sean dan kode batch OO 1220 yang di produksi oleh Balai Besar Inseminasi Buatan Singosari.

\section{Perlakuan}

Sebelum pendistribusian, dilakukan penghitungan jumlah straw yang dilakukan di dalam kontainer yang berisi nitrogen cair. Dalam penelitian ini straw diletakkan di atas rak dengan beberapa jarak dari nitrogen cair, dengan perlakuan sebagai berikut :

- P1 : straw diletakkan pada jarak $1 \mathrm{~cm}$ dari nitrogen cair selama 10 detik

- P2 : straw diletakkan pada jarak $1 \mathrm{~cm}$ dari nitrogen cair selama 20 detik

- P3 : straw diletakkan pada jarak $1 \mathrm{~cm}$ dari nitrogen cair selama 40 detik

- P4 : straw diletakkan pada jarak $2 \mathrm{~cm}$ dari nitrogen cair selama 10 detik

- P5 : straw diletakkan pada jarak $2 \mathrm{~cm}$ dari nitrogen cair selama 20 detik

- P6 : straw diletakkan pada jarak $2 \mathrm{~cm}$ dari nitrogen cair selama 40 detik

- P7 : straw diletakkan pada jarak $3 \mathrm{~cm}$ dari nitrogen cair selama 10 detik

- P8 : straw diletakkan pada jarak $3 \mathrm{~cm}$ dari nitrogen cair selama 20 detik

- P9 : straw diletakkan pada jarak $3 \mathrm{~cm}$ dari nitrogen cair selama 40 detik

\section{Pemeriksaan Motilitas Spermatozoa Post Thawing}

Penilaian dilakukan berdasarkan persentase gerak individu spermatozoa yang progresif dan kecepatan gerak individu spermatozoa dari minimal 5 lapang pandang. Penentuan presentase motilitas spermatozoa oleh susilowati (2010) dapat menggunakan rumus :

$\%$ motilitas spermatozoa $=$ $\frac{\text { jumlah spermatozoa progresif }}{\text { total spermatozoa yang diamati }} \times 100 \%$

\section{Pemeriksaan Viabilitas Spermatozoa Post Thawing}

Pada spermatozoa yang hidup tidak akan terwarnai oleh zat warna, sedangkan spermatozoa yang mati akan terwarnai. Spermatozoa yang mati berwarna merah keunguan dan yang hidup berwarna putih tanpa warna (Susilowati dkk., 2010).

\section{Rancangan Penelitian}

Penelitian ini menggunakan rancangan faktorial dua arah dengan interaksi lama waktu penghitungan straw dan posisi jarak straw di atas permukaan nitrogen cair serta ulangan yang diberikan adalah 6 kali.

\section{Hasil}

Hasil analisis menggunakan ANOVA menunjukan bahwa kombinasi antara lama waktu penghitungan straw dan posisi jarak straw di atas nitrogen cair berpengaruh nyata $(\mathrm{P}<0,05)$ terhadap motilitas spermatozoa sapi Madura post thawing. Data hasil pemeriksaan persentase motilitas spermatozoa sapi Madura post thawing disajikan pada Tabel 1. Hasil uji BNJ menunjukan bahwa rerata persentase motilitas spermatozoa sapi Madura post thawing paling tinggi pada $\mathrm{P} 3$ dan tidak berbeda nyata $(\mathrm{P}>0,05)$ terhadap $\mathrm{P} 2, \mathrm{P} 4$ dan P5. Rerata persentase motilitas spermatozoa sapi Madura post thawing paling rendah pada $\mathrm{P} 9$ dan tidak berbeda nyata $(\mathrm{P}>0,05)$ terhadap P1, P6, P7 dan P8.

Hasil analisis menggunakan ANOVA menunjukan bahwa jarak posisi straw di atas nitrogen cair berpengaruh nyata $(\mathrm{P}<0,05)$ terhadap viabilitas spermatozoa post thawing. Data hasil pemeriksaan viabilitas spermatozoa sapi Madura post thawing setelah dilakukan penghitungan pada jarak tertentu disajikan pada Tabel 2 .

$\%$ viabilitas spermatozoa $=$ $\frac{\text { jumlah spermatozoa hidup }}{\text { total spermatozoa yang dihitung }} \times 100 \%$

Hasil uji BNJ menunjukan bahwa jarak $1 \mathrm{~cm}$ tidak berbeda nyata $(\mathrm{P}>0,05)$ terhadap jarak $2 \mathrm{~cm}$, dan memiliki rerata persentase viabilitas spermatozoa sapi Madura post thawing paling tinggi. Jarak $3 \mathrm{~cm}$ memiliki rerata persentase viabilitas spermatozoa sapi Madura post thawing paling rendah. jarak $3 \mathrm{~cm}$ berbeda nyata $(\mathrm{P}<0,05)$ terhadap jarak $1 \mathrm{~cm}$ dan $2 \mathrm{~cm}$.

Hasil pemeriksaan viabilitas spermatozoa dengan pewarnaan eosin-negrosin me- 
Tabel 1. Motilitas Spermatozoa Sapi Madura post thawing

Lama Waktu

Penghitungan Straw
Jarak Posisi Straw di Atas Nitrogen Cair

$1 \mathrm{~cm} \quad 2 \mathrm{~cm} \quad 3 \mathrm{~cm}$

$\begin{array}{llll}10 \text { detik } & 40,83^{\mathrm{abc}} \pm 2,04 & 42,50^{\mathrm{bcd}} \pm 2,74 & 40,00^{\mathrm{ab}} \pm 0,00 \\ 20 \text { detik } & 45,00^{\mathrm{cd}} \pm 3,16 & 42,50^{\mathrm{bcd}} \pm 2,74 & 40,00^{\mathrm{ab}} \pm 0,00 \\ 40 \text { detik } & 46,67^{\mathrm{d}} \pm 2,58 & 40,83^{\mathrm{abc}} \pm 2,04 & 37,50^{\mathrm{a}} \pm 2,74\end{array}$

Superskrip yang berbeda pada kolom yang sama menunjukkan perbedaan yang nyata $(\mathrm{P}<0,05)$

Tabel 2. Viabilitas Spermatozoa Sapi Madura Post Thawing pada Jarak Tertentu di atas Permukaan Nitrogen Cair

\begin{tabular}{ccc}
\hline $\begin{array}{c}\text { Jarak Posisi Straw di atas Nitrogen } \\
\text { Cair }\end{array}$ & Ulangan & $\begin{array}{c}\text { Viabilitas Spermatozoa } \\
\text { (rerata } \pm \text { standar } \\
\text { deviasi) }\end{array}$ \\
\hline $1 \mathrm{~cm}$ & 18 & $65,61^{\mathrm{b}} \pm 10,55$ \\
$2 \mathrm{~cm}$ & 18 & $62,00^{\mathrm{b}} \pm 6,51$ \\
$3 \mathrm{~cm}$ & 18 & $46,61^{\mathrm{a}} \pm 8,31$ \\
\hline
\end{tabular}

Superskrip yang berbeda pada kolom yang sama menunjukkan perbedaan yang nyata $(\mathrm{P}<0,05)$.

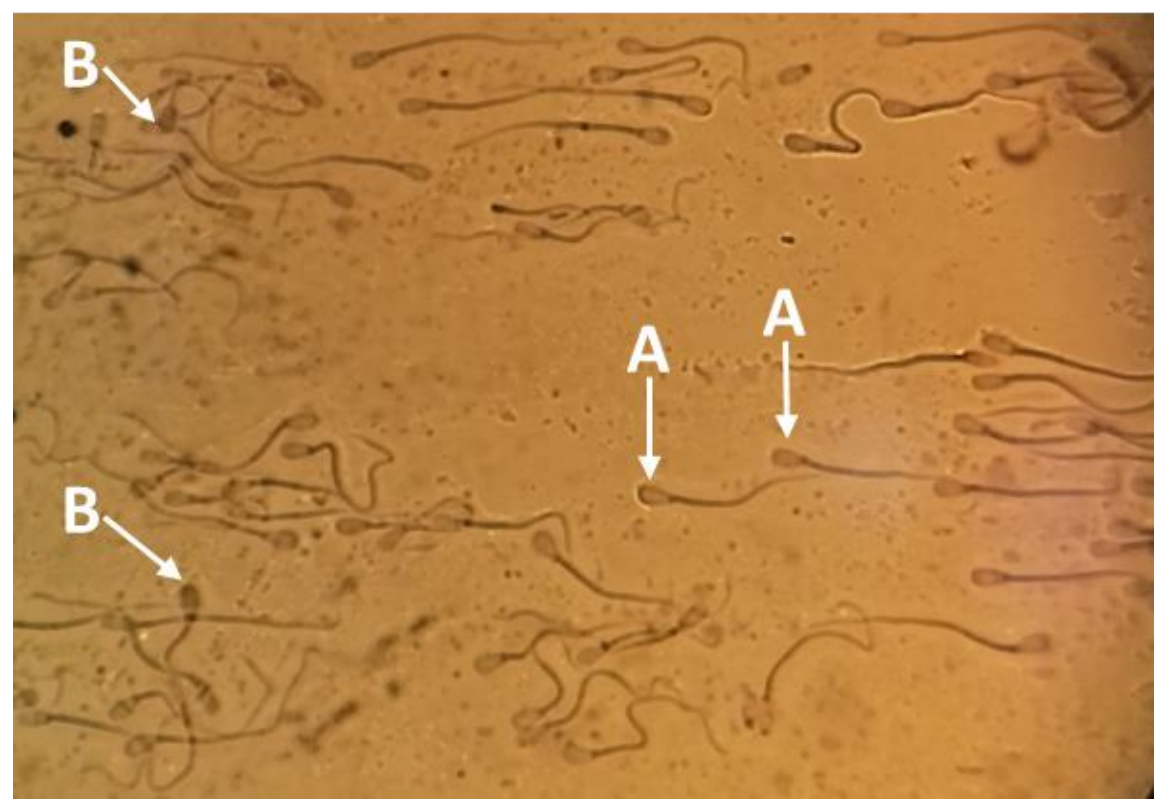

Gambar 1. Pemeriksaan Mikroskop Viabilitas Spermatozoa dengan Metode Preparat Ulas pada Perbesaran 400x (A. Spermatozoa hidup, kepala spermatozoa transparan dan B. Spermatozoa mati, kepala spermatozoa berwarna gelap)

nunjukan adanya spermatozoa yang hidup dan mati disajikan pada gambar 1 .

\section{Pembahasan}

Perlakuan P1 sampai P8 menunjukan rerata PTM semen beku sapi Madura sesuai dengan standar (SNI 4869.1:2008) yaitu lebih dari $40 \%$. Hal ini juga sesuai dengan hasil penghitungan semen beku di BBIB
Singosari yaitu senilai 40-45\%. P9 menunjukan rerata PTM sebesar 37,50 $\pm 2,74$. PTM semen beku dibawah $40 \%$ tidak dapat didistribusikan karena dapat menurunkan tingkat fertilitas. Rendahnya rerata PTM pada P9 dapat disebabkan oleh tingginya straw di atas permukaan nitrogen cair serta lamanya waktu penghitungan sehingga menurunkan nilai motilitas. 
Pada Gambar 4.1 menunjukan bahwa terjadi penurunan rerata persentase motilitas spermatozoa sapi Madura post thawing dari jarak $1 \mathrm{~cm}-3 \mathrm{~cm}$ pada waktu 20 detik dan 40 detik hal ini dikarenakan setiap kenaikan posisi straw dari nitrogen cair terjadi kenaikan suhu lingkungan sehingga akan mempengaruhi motilitas spermatozoa. Sedangkan pada waktu 10 detik jarak $1 \mathrm{~cm}$ pada diagram batang menunjukan nilai rerata persentase motilitas yang lebih rendah dari jarak $2 \mathrm{~cm}$, namun terjadi penurunan kembali pada jarak $3 \mathrm{~cm}$ hal ini disebabkan karena dalam penelitian kali ini pengamatan motilitas spermatozoa menggunakan mikroskop cahaya tanpa visualisasi dengan komputer. Simmet (2004) dan Farrel et al. (1995) menyebutkan bahwa pengujian motilitas spermatozoa menggunakan Computer Assisted Semen Analysis (CASA) mampu mengatasi subyektifitas penilaian sebab metode ini didasarkan atas pengembangan digital-image teknologi dan menghasilkan data dengan akurasi yang tinggi.

Perlakuan P3 menunjukan rata-rata persentase motilitas spermatozoa post thawing lebih tinggi dibanding perlakuan lain dan hasil tersebut tidak berbeda nyata $(\mathrm{P}>0.05)$ dengan $\mathrm{P} 2, \mathrm{P} 4$ dan P5. Posisi straw pada jarak 1-2 $\mathrm{cm}$ di atas permukaan nitrogen cair memiliki suhu $\pm-185,5^{\circ} \mathrm{C}$ (Lim et al., 2010), hal ini memungkinkan tidak terjadi perbedaan nyata terhadap motilitas spermatozoa sapi Madura post thawing. Nur et al. (2006) juga melaporkan pada suhu $-180^{\circ} \mathrm{C}$ rata-rata persentase spermatozoa sapi perah Friesian holstein setelah thawing masih menunjukan nilai yang sesuai dengan standar semen beku yang layak untuk diinseminasikan.

Perlakuan P9 menunjukan rerata persentase motilitas spermatozoa post thawing paling rendah tidak berbeda nyata $(\mathrm{P}>0,05)$ terhadap P1, P6, P7 dan P8. Pada jarak 3 $\mathrm{cm}$ suhu uap nitrogen cair mengalami peningkatan yang dapat mempengaruhi metabolisme dan integritas membran plasma sel spermatozoa yang berakibat pada menurunnya motilitas. Pada lama waktu 40 detik tingkat kerusakan membran plasma semakin parah.

Motilitas sperma dapat terjadi jika sperma mempunyai membran yang berfungsi dengan baik untuk menghasilkan energi gerak. Selama pembekuan terjadi perubahan suhu dan osmolalitas yang ekstrim sehingga akan merusak komposisi lipid membran plasma yang berdampak pada menurunnya motilitas sperma (Sukmawati dkk., 2014). Cerolini et al. (2001), Dziekonska et al. (2009) dan Gillan et al. (2004) juga menyatakan bahwa pendinginan dan pemanasan kembali akan merusak lipoprotein yang ada pada membran sperma. Perubahan struktur yang dihasilkan dalam membran sel sperma setelah thawing teru-tama terkait dengan kemampuan untuk mengubah sumber energi. Hal ini memengaruhi metabolisme seluler dan fungsi sperma seperti motilitas.

Hasil analisis statistik ANOVA menunjukan jarak straw dari permukaan nitrogen cair berpengaruh nyata terhadap viabilitas spermatozoa sapi Madura post thawing dengan nilai signifikansi 0,000 $(\mathrm{P}<0,05)$. Spermatozoa sensitif terhadap perubahan suhu utamanya pada plasma membran karena merupakan bagian utama terjadinya kerusakan yang disebabkan oleh pembekuan. Pembekuan dan thawing menyebabkan perubahan aktivitas protein sehingga dapat merubah permeabilitas membran (Bailey et al., 2003).

Pada penelitian ini didapatkan hasil rerata dan standar deviasi viabilitas spermatozoa post thawing paling tinggi pada jarak $1 \mathrm{~cm}$ sebesar $65,61^{\mathrm{b}} \pm 10,55$ hal ini dikarenakan pada jarak $1 \mathrm{~cm}$ suhu uap nitrogen cair tidak mengalami kenaikan yang drastis dari suhu didalam nitrogen cair $-196^{\circ} \mathrm{C}$. Spermatozoa yang memiliki persentase hidup yang tinggi menandakan bahwa membran plasma masih utuh secara fisik, sehingga organel sel spermatozoa akan terlindungi, kebutuhan zat-zat makanan dan ion-ion untuk proses metabolisme tersedia (Hidayatin., 2002).

Selama proses pembekuan hingga thawing spermatozoa terpapar stressful environment yaitu cold shock, osmotic stress dan kristalisasi, hal tersebut termasuk terjadinya peningkatan suhu dari $-196^{\circ} \mathrm{C}$ ke suhu uap nitrogen cair dengan beberapa jarak tertentu ketika dilakukan proses penghitungan straw. Paparan tersebut mengakibatkan kerusakan irreversible pada struktur dan fungsi sel yang mana dapat menurunkan hingga $50 \%$ viabilitas spermatozoa post thawing (Celeghini et al., 2008 dan Watson et al., 2000). 
Stressful environment selama proses pembekuan seperti cold shock, osmotic stress dan kristalisasi menyebabkan kerusakan pada integritas spermatozoa, struktur membran dan fungsi sel spermatozoa (Yoon et al., 2015). Cold shock terjadi karena adanya penurunan suhu secara mendadak sampai di bawah $0^{\circ} \mathrm{C}$. Secara umum cold shock menyebabkan penurunan metabolisme sel, mengubah permeabilitas membran, hilangnya komponen intraseluler dan meningkatkan jumlah kematian spermatozoa (Lemma, 2011).

Proses cooling rate spermatozoa yang berbeda di lapangan menghasilkan kurva cooling rate dan tingkat kematian spermatozoa yang berbeda (Pareira et al., 2010). Pada cooling rate cepat, air intraseluler tidak dapat keluar secara maksimal sehingga akan membeku dan membentuk kristal es didalam sitoplasma yang menyebabkan kerusakan sel irreversible. Sebaliknya pada cooling rate lambat, sebagian besar air akan mengalir keluar sehingga sel akan mengalami dehidrasi yang menyebabkan peningkatan konsentrasi intrasel serta penyusutan volume organel dan membran. Hal tersebut dapat mempengaruhi kompleks lipid-protein, denaturasi makromolekul dan memicu kerusakan permeabilitas membran yang bersifat irreversible (Yeste, 2015).

\section{Kesimpulan}

Penghitungan straw jarak $1 \mathrm{~cm} 40$ detik di atas permukaan nitrogen cair menghasilkan rerata persentase motilitas spermatozoa sapi Madura post thawing paling baik dibanding perlakuan lain.

\section{Daftar Pustaka}

Affandhy, L., Pamungkas, D., Wijono, B., Prihandini, P.W., Situmorang, P., Pratiwi, W.C. 2006. Peningkatan Produktivitas Sapi Potong Mela-lui Efisiensi Reproduksi. Laporan Akhir. Loka Penelitian Sapi Po-tong.

Afiati, F., Kaiin, E.M., Gunawan, M., Said, S., dan Tappa, B. 2004. Kualitas dan kemampuan hidup sperma beku sapi PO setelah tha-wing. J. Protein 11 (2): 205-212.

Bailey, J.L., Morrie, A. and Cormier, N. 2003. Semen cryopreservation: success and persistent in farm species. Canadian J. Anim. Sci. 83: 393-401.

Caraviello, D.Z., Weigel, K.A., Fricke, P.M., Wiltbank, M.C., Florent, M.J., Cook, M.B., Norlund, K.V., Zwald, N.R., Rawson, C.L. 2006. Survey of Management Practices on Reproductive Performance of Dairy Cattle on Large US Comercial Farms. Journal of Dairy Science. 89(12) : 4723 4735.

Celeghini, E.C., de Arruda, R.P., de Andrade, A.F., Nascimento, J., Raphael, C.F., Rodrigues, P.H. 2008. Effects that bovine sperm cryopreservation using two different extenders has on sperm membranes and chromatin. Animal reproduction science. 104(2-4) : 119-31.

Cerolini, S., Maldjian, A., Pizzi, F., Gliozzi, T.M. 2001. Changes in sperm quality and lipid composition during cryopreservation of Boar semen. Reproduction. 121: 395-401.

Diwyanto, K. 2012. Pokok - Pokok Pemikiran Pengelolaan Berkelanjutan Plasma Nutfah Peternakan. Loka Karya Plasma Nutfah Peternakan 29 Desember 2005. Puslitbangnak dan Balitnak. Bogor.

Dziekońska, A., Fraser, L., Strzeżek, J. 2009. Effect of different storage temperatures on themetabolic activity of sperm following liquid storage of Boar semen. J Anim Feed Sci. 18: 638-649.

Farrell, P.B., Trend, T.V., Foote, R.H., Hamilton D.D. 1995. Repeatability of measurements on human, rabbit, and bull sperm by computer-assisted sperm analysis when comparing individual fields and means of 12 fields. Fertil Steril. 64: 208-10.

Gillan, L., Maxwell, W.M.C., Evans, G. 2004. Preservation and evaluation of semen for artificial insemi-nation. Reprod Fertil Dev. 16: 447-454.

Hidayati. 2002. Tingkat Keberhasilan Pelaksanaan Inseminasi Buatan pada Ternak Sapi di kecamatan Kayu Aro Kabupaten Kerinci. Skripsi. Fakultas Peternakan Universitas Andalas. Padang.

Lemma, A. 2011. Effect of Cryopreservation on Sperm Quality and Fertility 
In Artificial Insemination in Farm Animals. Addis Ababa University. School of Veterinary Medicine. Debre Zeit Ethiopia.

Lim, J.J., Shin, T.E., Song, S.H., Bak, C.W., Yoon, T.K., Lee, D.R. 2010. Effect of liquid nitrogen vapor storage on the motility, viability, morphology, deoxyribo-nucleic acid integrity, and mitochondrial potential of frozen-thawed human spermatozoa. Fertil Steril. 94: 2736-41.

Nur, Z., Ileri, I.K., Ak, K. 2006. Effect of Different Temperature Treatments Applied to Deep Stored Bull Se-men on Post-Thaw Cold Shocked Spermatozoa. Bull Vet Inst Pul-away. 50: 7983.

Pareira, G.R., Becker, E.G., Siqueira, L.C., Ferreira, R., Severo, C.K., Truzzi, V.S., Oliveira, J.F.C., Goncalves, P.B.D. Assesment of Bovine Spermatozoa Viability Using Different Cooling Protocols Prior to Cryopreservation.

Prihatno, S.A., Kusumawati, A., Karja, N.W.K., Sumiarto, B. 2013. Prevalensi dan Faktor Resiko Kawin Berulang pada Sapi Perah pada Tingkat Peternak. Jurnal Veteriner. 14(4): $452-461$.

Riady, M. 2006. Implementasi Program Menuju Swasembada Daging 2010.
Strategi dan Kendala. Seminar Nasional Teknologi Peternakan dan Veteriner. Puslitbangnak. Bogor. 5-6.

Selk, G. 2002. Artificial insemination for beef cattle. http://www.osuextra.com. (5 juni 2017).

SNI 01-4869.1-2008. Semen Beku Sapi. Sisni.bsn.go.id/index.php?/sni_main/ sni/detail_sni/7026.

Sukmawati, E., Arifiantini, R.I. dan Purwantara, B. 2014. Daya Tahan Spermatozoa terhadap Proses Pembekuan pada Berbagai Jenis Sapi Pejantan Unggul. Fakultas Kedokteran Hewan. Institut Pertanian Bogor. Bogor.

Watson, P.F. 2000. The Causes of Reduced Fertility with Cryopreserved Semen. Animal Reproduction Science. 60: 481-92.

Yeste, M. 2015. Sperm Cryopreservation Update : Cryodamage, Markers and Factors Affecting The Sperm Freezability in Pigs. Theriogenology.

Yoon, S.J., Kwon, W.S., Rahman, M.S., Lee, J.S., Pang, M.G. 2015. A Novel Approach to Identifying Physical Markers of Cryo-Damage in Bull Spermatozoa. Department of Animal Science and Technology. Chung-Ang University. Gyeonggido. Republic of Korea. Plosone. 10(05). 